\title{
A PRELIMINARY STUDY ON THE DISTRIBUTION OF BREEDING SITES OF Biomphalaria glabrata IN THE MUNICIPALITY OF PERI MIRIM, A LOW ENDEMICITY AREA FOR SCHISTOSOMIASIS IN NORTHEAST BRAZIL
}

Andrea Teles dos Reis ${ }^{1}$, Carla Fernanda do Carmo Silva ${ }^{1}$, Raynara Fernanda Silva Soares ${ }^{1}$, Diogo Tavares Cardoso², João Gustavo Mendes Rodrigues ${ }^{2}$, Ranielly Araújo Nogueira ${ }^{3}$, Guilherme Silva Miranda ${ }^{2,4}$, and Nêuton SilvaSouzal

\section{ABSTRACT}

Information on areas colonized by snails that transmit Schistosoma mansoni is essential for planning schistosomiasis control measures. Therefore, the purpose of this study was to map the natural breeding sites of Biomphalaria spp. in the municipality of Peri Mirim, Maranhão, Brazil. The snails were manually collected and the breeding sites were geo-referenced (seven in the urban area and five in flooded fields), from November 2017 to March 2018. In the laboratory, the snails were examined for the presence of larval stages of $S$. mansoni identified by morphology and internal anatomy analysis. While no snails were found in the urban area, sixteen B. glabrata were collected in the flooded fields. No S. mansoni or other trematode infections were detected. Wild rodents, most likely Holochilus sciureus that could act as $S$. mansoni reservoirs, were also found in the flooded fields. These data indicate possible risk areas for further outbreaks of schistosomiasis transmission in the municipality of Peri Mirim.

KEY WORDS: Baixada Maranhense; malacological survey; planorbidae; spatial analysis.

\footnotetext{
1. State University of Maranhão, Department of Chemistry and Biology, São Luís, MA, Brazil.

2. Federal University of Minas Gerais, Department of Parasitology, Belo Horizonte, MG, Brazil.

3. Federal University of Maranhão, Department of Pathology, São Luís, MA, Brazil.

4. Federal Institute of Maranhão, Department of Biology, São Raimundo das Mangabeiras, MA, Brazil.
}

Andrea Teles dos Reis https://orcid.org/0000-0002-3231-1183; Carla Fernanda do Carmo Silva https://orcid.org/0000-0002-97795932; Raynara Fernanda Silva Soares https:/orcid.org/0000-0001-6617-110X; Diogo Tavares Cardoso https://orcid.org/00000002-7375-4837; João Gustavo Mendes Rodrigues https://orcid.org/0000-0003-0920-4977; Ranielly Araújo Nogueira https:// orcid.org/0000-0002-9470-0918; Guilherme Silva Miranda https:/orcid.org/0000-0003-3763-2776; Nêuton Silva-Souza https:// orcid.org/0000-0001-8912-017X 


\section{INTRODUCTION}

Schistosomiasis is one of the most important parasitic diseases in the world, as it affects approximately 240 million people in more than 78 countries, mainly in tropical and subtropical regions, and is associated with severe morbidity in human populations in endemic areas (WHO, 2018). The etiologic agent of this disease in Brazil is the parasite of the species Schistosoma mansoni Sambon, 1907, a heteroxenous trematode that needs a vertebrate host, mostly humans and wild mammals (Rey, 1993; Miranda et al., 2017), and a susceptible invertebrate host, some snail species of the genus Biomphalaria (Coelho et al., 2008; Scholte et al., 2012). Three main Biomphalaria species are responsible for the transmission of schistosomiasis in Brazil: B. glabrata (Say, 1818), B. tenagophila (d'Orbigny, 1835) and B. straminea (Dunker, 1848; Brazil, 2008).

In malacological surveys carried out in the Brazilian State of Maranhão, B. glabrata and B. straminea were found, but only B. glabrata was naturally infected with S. mansoni (Santos et al., 2011; Oliveira et al., 2013; Cantanhede et al., 2014; Nogueira et al., 2016; Miranda et al., 2016; Rodrigues et al., 2017). The infected mollusks were found mainly in the northern region of the state, including São Luís (the state capital), and in the Baixada Maranhense Microregion (western Maranhão). Indeed, the Baixada Maranhense remains one of the main areas of active schistosomiasis transmission in Maranhão (Mendes et al., 2017). This region is characterized by extensive flooded fields, favoring activities such as fishing, hunting and agriculture, all of which enhance the risk of human infections by S. mansoni (Lira et al., 2017). Moreover, the maintenance of the $S$. mansoni life cycle in the Baixada Maranhense is possibly associated with the presence of the semi-aquatic rodents of the species Holochilus sciureus, naturally infected with $S$. mansoni (Veiga-Borgeaud et al., 1986; Do Carmo-Silva et al., 2019).

Peri Mirim is one of the 21 municipalities comprising the Baixada Maranhense and presented a S. mansoni prevalence of 2.4\% in 2017 (Brazil, 2018). Despite being included in a recent qualitative malacological survey (Cantanhede et al., 2014), the detailed distribution of host snails in the surroundings of this municipality remains unknown. Thus, we aimed to evaluate the spatial distribution of natural Biomphalaria spp. breeding sites in the municipality of Peri Mirim, Maranhão, Brazil, which may improve the strategies for the local control of schistosomiasis.

\section{MATERIAL AND METHODS}

\section{Study area}

Peri Mirim (2॰34'41.6”S 4451'32.8'W) has a population of 14,345 inhabitants, with an area of $398,721 \mathrm{~km}^{2}$ (Brazil, 2020), divided into two main 
zones: the urban area and the flooded fields (Figure 1). It has a humid tropical climate, with two well-defined seasons: the rainy season from January to July, and the dry season from August to December (Costa-Neto et al., 2001). It is a region with low endemicity for schistosomiasis, with a prevalence of less than $5 \%$ (Brazil, 2005).

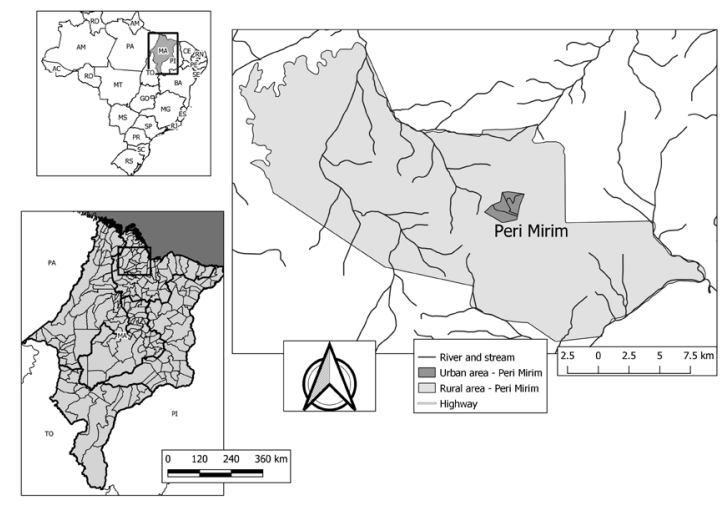

Figure 1. Geographic location of the municipality of Peri Mirim, State of Maranhão, Brazil.

\section{Malacological survey}

Freshwater mollusks were collected between November 2017 and March 2018 using an active search sampling technique in all water accumulation sites located in the urban area and the flooded fields in the study zone. The study was approved by the Chico Mendes Institute for Biodiversity Conservation (license number 40025/1) and registered in the National System for the Management of Genetic Heritage and Associated Traditional Knowledge (registration number A97213B). Manual snail collection was carried out by three trained persons using metal tweezers and metal dip nets in a radius of approximately $30 \mathrm{~m}(10$ $\mathrm{m} /$ trained person) for $30 \mathrm{~min}$ in each collection point (adapted from Barboza et al., 2012). The collected mollusks were stored in plastic containers, which were identified with the date, location, and collection point and taken to the laboratory.

All collection points were geo-referenced (even those with no water accumulation and mollusks) with a GPS (Global Positioning System) receiver (Garmin Etrex ${ }^{\circledR}$ ) and the spatial distribution of Biomphalaria spp. was built using the Qgis program, version 2.18. Rainfall data were obtained from a publically available database by PROCLIMA/CPTEC (http://proclima.cptec. inpe.br), and the average rainfall in each collection month was calculated. 
In the laboratory, the mollusks were kept in glass aquariums with dechlorinated water and fed lettuce leaves. To verify the shedding of trematode larvae, the snails were individually placed in glass containers with $5 \mathrm{~mL}$ of dechlorinated water, exposed to light and heat from three incandescent light bulbs $(60 \mathrm{~W})$ for $4 \mathrm{~h}$ and analyzed. Subsequently, the same snails were left in a dark room for $12 \mathrm{~h}$ before further analysis, as the cercariae from some species are shed at night. These procedures were performed once a week for sixty days. Subsequently, the negative mollusks were crushed to confirm the absence of other trematode life stages in soft tissues (Brazil, 2008). All live specimens underwent parasitological analysis and were then processed according to Fernandez et al. (2008) and identified using conchological and internal morphological parameters (Paraense, 1975).

\section{RESULTS}

Sixteen Biomphalaria spp. specimens were collected, belonging to the species B. glabrata found in the flooded fields (Paciência, $\mathrm{n}=7$; Agostinho, $\mathrm{n}$ $=4$; Murriré, $n=3$; Ilha da Pedra, $n=2)($ Table). Despite the apparent absence of snails in the urban area, street names were recorded to enable further location of the collection points (Figure 2). None of the collected snails was found to be infected with either $S$. mansoni or other digenetic trematodes. The rainfall average of each month was quite irregular, varying from $0.06 \mathrm{~mm}$ in November/2017 to $6.8 \mathrm{~mm}$ in March/2018 (Table).

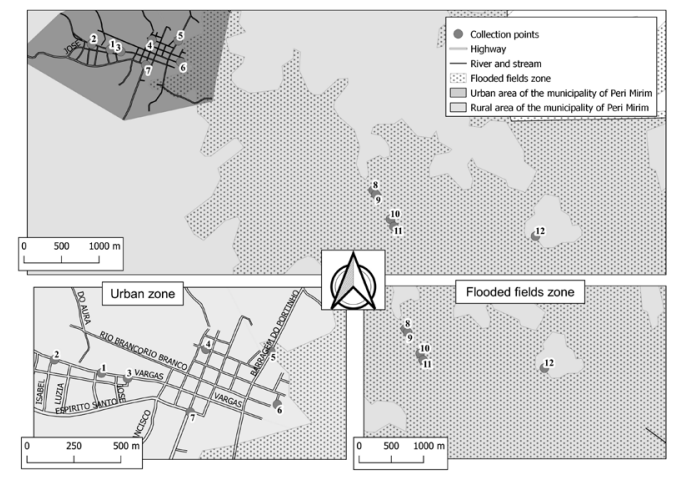

Figure 2. Distribution of Biomphalaria glabrata collection points in urban and flooded field zones in the municipality of Peri Mirim, State of Maranhão, Brazil. Points 1 and 2= Campo de Pouso; 3 and $4=$ Centro; 5 and $6=$ Portinho; 7 = São Francisco; 8 = Canarã; 9 = Murriré; $10=$ Paciência; 11 = Ilha da Pedra; $12=$ Agostinho. 
Regarding the characteristics of the collection points, Campo de Pouso and Centro had paved streets with no evident water collection. On the other hand, the Portinho and São Francisco points had small, shallow streams at the doors of the houses, but with no vegetation in such potential breeding sites. The flooded fields (Canarã, Agostinho, Ilha da Pedra, Murriré and Paciência) were characterized by the presence of both shallow and deep freshwater collection, with the presence of abundant aquatic vegetation (Figure 3, A-E). It is also important to highlight the presence of Holochilus spp. rodents, most likely $H$. sciureus, in the flooded fields, an animal regarded as a wild infection reservoir of $S$. mansoni in the region (Figure 3, F).

Table. Number of Biomphalaria glabrata collected in the flooded fields and neighborhoods of the municipality of Peri Mirim, State of Maranhão, Brazil.

\begin{tabular}{|c|c|c|c|c|c|c|}
\hline Zone & Neighborhood & Point & $\begin{array}{l}\text { Geographic } \\
\text { coordinates }\end{array}$ & $\begin{array}{l}\text { Number } \\
\text { of snails }\end{array}$ & $\begin{array}{c}\text { Collection } \\
\text { data }\end{array}$ & $\begin{array}{l}\text { Average } \\
\text { Rainfall }\end{array}$ \\
\hline \multirow[t]{7}{*}{ Urban } & \multirow{2}{*}{ Campo de Pouso } & 1 & $\begin{array}{c}2^{\circ} 34^{\prime} 40.7^{\prime \prime} \mathrm{S} \\
44^{\circ} 51^{\prime} 37.3 \text { ' } \mathrm{W}\end{array}$ & 0 & Nov./2017 & \multirow{3}{*}{$0.06 \mathrm{~mm}$} \\
\hline & & 2 & $\begin{array}{c}2^{\circ} 34^{\prime} 38.4 ” \mathrm{~S} \\
44^{\circ} 51^{\prime} 45.4^{\prime \prime} \mathrm{W}\end{array}$ & 0 & Nov./2017 & \\
\hline & \multirow{2}{*}{ Centro } & 3 & $\begin{array}{c}2^{\circ} 34^{\prime} 41.6^{\prime \prime} \mathrm{S} \\
44^{\circ} 51^{\prime} 32.8^{\prime \prime} \mathrm{W}\end{array}$ & 0 & Nov./2017 & \\
\hline & & 4 & $\begin{array}{c}2^{\circ} 34^{\prime} 36.6^{\prime \prime} \mathrm{S} \\
44^{\circ} 51^{\prime} 19.3 ” \mathrm{~W}\end{array}$ & 0 & Nov./2017 & \multirow{4}{*}{$1.7 \mathrm{~mm}$} \\
\hline & \multirow{2}{*}{ Portinho } & 5 & $\begin{array}{c}2^{\circ} 34^{\prime} 37.0^{\prime \prime} \mathrm{S} \\
44^{\circ} 51^{\prime} 08.1 \text { '” }\end{array}$ & 0 & Dec./2017 & \\
\hline & & 6 & $\begin{array}{c}2^{\circ} 34^{\prime} 46.1^{\prime \prime} \mathrm{S} \\
44^{\circ} 51^{\prime} 07.0^{\prime \prime} \mathrm{W}\end{array}$ & 0 & Dec./2017 & \\
\hline & São Francisco & 7 & $\begin{array}{l}2^{\circ} 34^{\prime} 47.4^{\prime \prime} \mathrm{S} \\
44^{\circ} 51^{\prime} 22^{\prime \prime} \mathrm{W}\end{array}$ & 0 & Dec./2017 & \\
\hline \multirow[t]{5}{*}{$\begin{array}{l}\text { Flooded } \\
\text { fields }\end{array}$} & Canarã & 8 & $\begin{array}{c}2^{\circ} 35^{\prime} 41.2^{\prime \prime} \mathrm{S} \\
44^{\circ} 49^{\prime} 44.1^{\prime \prime} \mathrm{W}\end{array}$ & 0 & Jan./2018 & \\
\hline & Murriré & 9 & $\begin{array}{c}2^{\circ} 35^{\prime} 43.0^{\prime \prime} \mathrm{S} \\
44^{\circ} 49^{\prime} 42.9^{\prime \prime} \mathrm{W}\end{array}$ & 3 & Jan./2018 & \multirow[t]{2}{*}{$6.36 \mathrm{~mm}$} \\
\hline & Paciência & 10 & $\begin{array}{c}2^{\circ} 35^{\prime} 53.6^{\prime \prime} \mathrm{S} \\
44^{\circ} 49^{\prime} 36.7^{\prime \prime} \mathrm{W}\end{array}$ & 7 & Jan./2018 & \\
\hline & Ilha da Pedra & 11 & $\begin{array}{c}2^{\circ} 35^{\prime} 56.8^{\prime \prime} \mathrm{S} \\
44^{\circ} 49^{\prime} 35.2^{\prime \prime} \mathrm{W}\end{array}$ & 2 & Mar./2018 & \multirow[t]{2}{*}{$6.8 \mathrm{~mm}$} \\
\hline & Agostinho & 12 & $\begin{array}{c}2^{\circ} 36^{\prime} 00.9 ” \mathrm{~S} \\
44^{\circ} 48^{\prime} 34.2 ” \mathrm{~W}\end{array}$ & 4 & Mar./2018 & \\
\hline
\end{tabular}




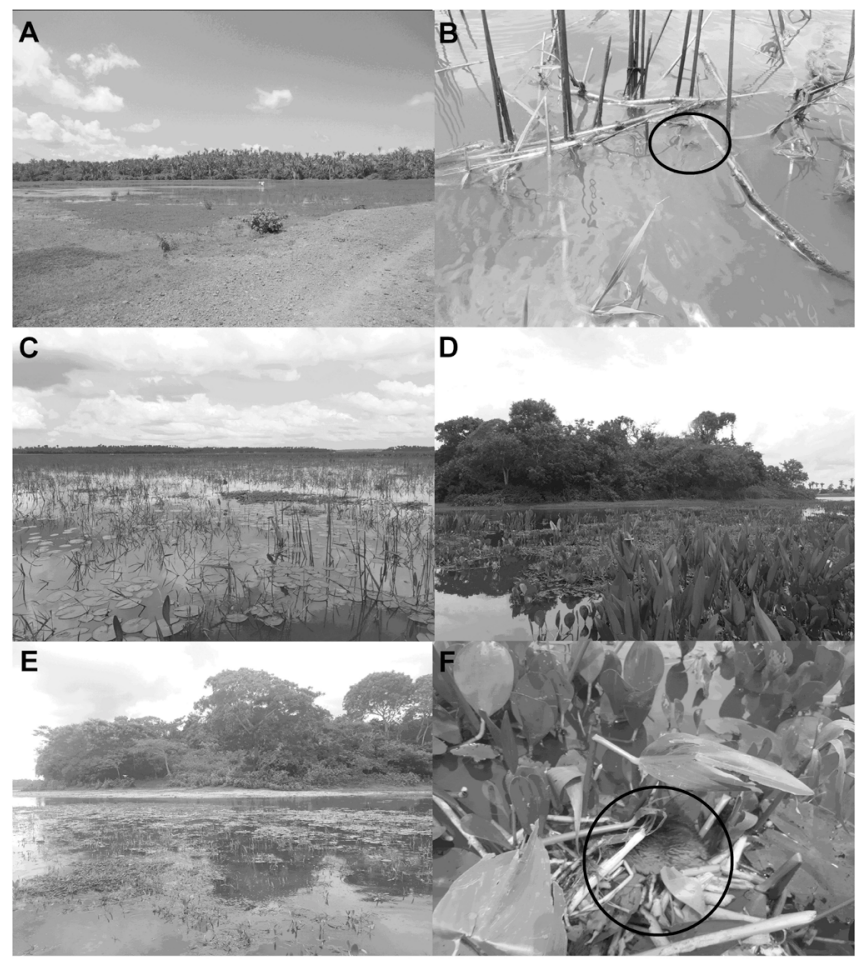

Figure 3. Environmental characteristics of collection points in the flooded field zone of the municipality of Peri Mirim, State of Maranhão, Brazil. A. Canarã. B. Agostinho (the circle indicates the presence of Biomphalaria glabrata). C. Ilha da Pedra. D. Murriré. E. Paciência. F. Presence of the rodent Holochilus spp. in the flooded fields (circle).

\section{DISCUSSION}

This is the first study to carry out a detailed spatial distribution of natural breeding sites for B. glabrata in the municipality of Peri Mirim, a low endemicity area for schistosomiasis in Northeastern Brazil, therefore a valuable record that can guide further interventions run by the epidemiological surveillance authorities to fight schistosomiasis in the region. The mapping of the geographic distribution of $S$. mansoni-transmitting snails has been used on a large scale in ecological and epidemiological studies (Guimarães et al., 2009; Barboza et al., 2012; Nogueira et al., 2016; Bezerra et al., 2018; David et al., 2018). This method allows the construction of maps that are fundamental in the planning of schistosomiasis control actions, as they enable visualization of snail breeding sites and increase knowledge regarding their distribution areas. 
Some Biomphalaria species were reported in Peri Mirim in a previous qualitative malacological survey, such as B. glabrata and B. schrammi (Crosse, 1864) (Cantanhede et al., 2014). However, this work is the first attempt to map out in detail the occurrence of B. glabrata in the municipality with greater precision, considering it is the most important species in the transmission of schistosomiasis in Brazil (Souza et al., 1995; Carvalho et al., 2008).

Although $S$. mansoni infection is considered active at low levels in the municipality, only a few B. glabrata snails were found and no infection was detected. The absence of snails at the collection points located in the urban area may be related to street paving in the Peri Mirim neighborhoods. Even though they may also inhabit artificial breeding sites, B. glabrata prefer habitats that are rich in organic matter, and urbanization may affect optimal conditions for a potential breeding site, reducing food availability and essential minerals (Bini et al., 1999; Abílio et al., 2006; de Assis Janasi et al., 2007). Moreover, rainfall in the studied period was irregular, and some previous studies correlate a higher density of snails with the rainy season (Giovanelli et al., 2001; Favre et al., 2002). Additionally, Miranda et al. (2016) and David et at. (2018) showed a positive relationship between high precipitation and increased Biomphalaria spp. occurrence. However, we did not investigate the collection points in all seasons, which did not allow us to establish a relationship between rainfall and the number of snails collected in the area.

The absence of trematode-infected snails may be due to the low number of specimens collected, as previous malacological surveys in the Baixada Maranhense have already shown that this area has a high trematode biodiversity, including S. mansoni (Cantanhede et al., 2014; Rodrigues et. al, 2017). Additionally, the low occurrence of $S$. mansoni larval stages in snails can be associated with the majority of the infected human population presenting low levels of parasitism, eliminating only a few eggs in feces (low parasite burden), which could make environmental contamination by eggs less likely and consequentially lead to lower infection rates in B. glabrata (Lira et al., 2017). However, the absence of infected B. glabrata does not rule out the possibility of there being active transmission of $S$. mansoni in the collection points or these potential breeding sites becoming future sources of $S$. mansoni human infections.

Among the investigated areas, the flooded fields may be potential sources of transmission, since only this area presented B. glabrata snails. Lira et al. (2017) demonstrated a higher prevalence of infection in individuals who constantly visited these fields for fishing, suggesting that the infection occurs more actively in the flooded fields than in the urban area. Furthermore, in these same flooded fields, Do Carmo-Silva et al. (2019) first reported the presence of the rodent $H$. sciureus naturally infected with $S$. mansoni and that their infection rate did not vary significantly in relation to distance from the urban zone. Therefore, the rodent $H$. sciureus might be the cause of a constant active focus of schistosomiasis in the location; however, this hypothesis requires further work. 
Although the malacological survey was only performed for five months, some main sites used for housing and fishing by the local population were preliminarily investigated. However, further work is necessary to better assess the influence of seasonality on the occurrence of B. glabrata in the municipality of Peri Mirim.

In summary, this study mapped in detail the natural breeding sites of B. glabrata, indicating areas at risk of possible outbreaks of S. mansoni transmission in the municipality of Peri Mirim, State of Maranhão. Our results also contribute to a better understanding of the B. glabrata area of occurrence in Northeastern Brazil and can help Peri Mirim health services in the control of schistosomiasis.

\section{CONFLICT OF INTEREST}

The authors declare that there is no conflict of interest.

\section{ACKNOWLEDGMENTS}

We thank the Conselho Nacional de Desenvolvimento Científico e Tecnológico $(\mathrm{CNPq})$ for the financial support and the Universidade Estadual do Maranhão for supplying transport to carry out the field research.

\section{REFERENCES}

1. Abílio FJP, Fonseca-Gessner AA, Leite RL, de Melo Ruffo TL. Gastrópodes e outros invertebrados do sedimento e associados à macrófita Eichhornia crassipes de um açude hipertrófico do semi-árido paraibano. Rev Biol Ciênc Terra 1: 165-178, 2006.

2. Barboza DM, Zhang C, Santos NC, Silva MMBL, Rollemberg CVV, de Amorim FJR, de Jesus AR. Biomphalaria species distribution and its effect on human Schistosoma mansoni infection in an irrigated area used for rice cultivation in northeast Brazil. Geospat Health 6: S103-S109, 2012 .

3. Bezerra FSDM, Pinheiro MCC, Silva Filho JDD, Castro IMND, Caldeira RL, Sousa MS, Ramos Júnior AN. Identification of Biomphalaria sp. and other freshwater snails in the largescale water transposition project in the Northeast of Brazil. Rev Inst Med Trop Sao Paulo 60: e41, 2018.

4. Bini LM, Thomaz SM, Murphy KJ, Camargo AFM. Aquatic macrophyte distribution in relation to water and sediment conditions in the Itaipu Reservoir, Brazil. Hydrobiologia 415: 147-154, 1999.

5. Brasil. Ministério da Saúde. Secretária de Vigilância em Saúde. Guia de vigilância epidemiológica. $6^{\circ}$ ed. Ed Ministério da Saúde: Brasília, 2005. 816 p.

6. Brasil. Instituto Brasileiro de Geografia e Estatística. Cidades, 2020. Available in: https:// cidades.ibge.gov.br/brasil/ma/peri-mirim/panorama. Acessed in: 18/11/2020.

7. Brasil. Ministério da Saúde. Sistema de informação do programa de vigilância e controle da esquistossomose, 2018. Available in: http: // tabne t.datas us.gov.br/cgi/defto htm.exe?sinan/ pce/cnv/pceMA.def. Accessed in: 18/11/2020. 
8. Brasil. Ministério da Saúde. Vigilância e controle de moluscos de importância epidemiológica: diretrizes técnicas: Programa de Vigilância e Controle da Esquistossomose. $2^{\mathrm{a}}$ ed. Ed Ministério da Saúde: Brasília, 2008. 180p.

9. Cantanhede SPD, Fernandez MA, Mattos ACD, Montresor LC, Silva-Souza N, Thiengo SC. Freshwater gastropods of the Baixada Maranhense Microregion, an endemic area for schistosomiasis in the State of Maranhão, Brazil: I-qualitative study. Rev Soc Bras Med Trop 47: 79-85, 2014.

10. Carvalho OS, Jannotti-Passos LK, Caldeira RL. Importância epidemiológica e biologia molecular aplicada ao estudo dos moluscos do gênero Biomphalaria. Schistosoma mansoni \& Esquistossomose: uma visão multidisciplinar. Fiocruz: Rio de Janeiro, 2008. p.311-345.

11. Coelho PMZ, Andrade Z de A, Borges CM da C, Ribeiro F, Barbosa L. Evolução de Schistosoma mansoni no hospedeiro intermediário. In: Carvalho OS, Coelho PMZ, Lenzi HL (org.). Schitosoma mansoni e esquistossomose: uma visão multidisciplinar. Fiocruz: Rio de Janeiro, 2008. p.147-160.

12. Costa-Neto JP, Barbieri R, do SR Ibañez M, Cavalcante PRS, Piorski NM. Limnologia de três ecossistemas aquáticos característicos da Baixada Maranhense. Bol Lab Hidrobiol 14/15: 1938,2001 .

13. de Assis Janasi V, de Assis Negri F, Montanheiro TJ, de Freitas VA, da Rocha BC, Reis PM. Geochemistry of the eocretacic basalt magmatism in the Piraju-Ourinhos region, SE Brazil, and implications to the stratigraphy of the Serra Geral Formation. Braz J Geol 37: 148-162, 2007.

14. David NF, Cantanhede SPD, Monroe NB, Pereira LPLA, Silva-Souza N, Abreu-Silva AL, de Oliveira VM, Tchaicka L. Spatial distribution and seasonality of Biomphalaria spp. in São Luís (Maranhão, Brazil). Parasitol Res 117: 1495-1502, 2018.

15. Do Carmo-Silva CF, Teles-Reis A, Silva-Soares RF, Rodrigues JGM, Lira MGS, Nogueira RA, Viegas-Melo D, Cardoso DT, Miranda GS, Silva-Souza N. Spatial and seasonal distribution of Holochilus sciureus with Schistosoma mansoni infection in an endemic area for schistosomiasis in Brazil. Acta Parasitol 64: 932-937, 2019.

16. Favre TC, Pieri OS, Zani LC, Ferreira JM, Domás GG, Beck LH, Barbosa CS. Longitudinal Study on the Natural Infection of Biomphalaria straminea and B. glabrata by Schistosoma mansoni in an Endemic Area of Schistosomiasis in Pernambuco, Brazil. Mem Inst Oswaldo Cruz 97: 465-475, 2002.

17. Fernandez MA, Thiengo SC, Amaral RS. Técnicas malacológicas. In: Amaral RS, Thiengo SC, Pieri OS (org.). Vigilância e Controle de Moluscos de Importância Epidemiológica: diretrizes técnicas. Ministério da Saúde: Brasília, 2008. p.43-70.

18. Giovanelli A, Soares MS, D’Andrea PS, Gonçalves MML, Rey L. Abundância e infecção do molusco Biomphalaria glabrata pelo Schistosoma mansoni no Estado do Rio de Janeiro, Brasil. Rev Saude Publ 35: 523-530, 2001.

19. Guimarães RJ, Freitas CC, Dutra LV, Felgueiras CA, Moura AC, Amaral RS, Carvalho OS. Spatial distribution of Biomphalaria mollusks at São Francisco River Basin, Minas Gerais, Brazil, using geostatistical procedures. Acta Trop 109: 181-186. 2009.

20. Lira MGS, Miranda GS, Rodrigues JGM, Nogueira RA, Gomes GCC, Silva-Souza N. Ocorrência de Schistosoma mansoni no município de São Bento, Baixada Ocidental Maranhense, estado do Maranhão, Brasil. Rev Pan-Amaz Saude 8: 45-51, 2017.

21. Mendes MFC, Ribeiro DML, Melo BO, Bomfim MRQ. Investigação epidemiológica da esquistossomose mansônica em municípios do Maranhão, Brasil. J Modelo Geospat 2: 12-18, 2017. 
22. Miranda GS, Miranda BS, Rodrigues JGM, Lira MGS, Nogueira RA, Viegas-Melo D, Silva-Souza N. Research Note. The wild water-rats and their relevance in the context of schistosomiasis mansoni in Brazil: what we know and recommendations for further research. Helminthologia 54: 165-169, 2017.

23. Miranda GS, Rodrigues JGM, Lira MGS, Nogueira RA, Gomes GCC, Miranda, BS, SilvaSouza N. Moluscos límnicos como hospedeiros de trematódeos digenéticos de uma região metropolitana da ilha do Maranhão, Brasil. Sci Plena 12: 1-11, 2016.

24. Nogueira RA, Lira MGS, Miranda GS, Rodrigues JGM, Gomes GCC, Silva-Souza N. Distribution of mollusks that transmit schistosomiasis in the endemic municipality of São Bento, Maranhão, Brazil. Rev Patol Trop 45: 295-304, 2016.

25. Oliveira DS, Nunes GS, Mendes RJ, França CRC, Filho AAP, Tavares CP, Rosa IG. Inquérito malacológico para identificar a célula de expansão da esquistossomose mansônica na Vila Embratel, um bairro de periferia de São Luís do Maranhão. Cad. Pesqui 20: 16-19, 2013.

26. Paraense WL. Estado atual da sistemática dos planorbídeos brasileiros. Arq Mus Nac 55: 105128, 1975.

27. Rey L. Non-human vertebrate hosts of Schistosoma mansoni and schistosomiasis transmission in Brazil. Res Rev Parasitol 53: 13-25, 1993.

28. Rodrigues JGM, Miranda GS, Lira MGS, Nogueira RA, Gomes GCC, Cutrim RS, Silva-Souza N. Larvas de trematódeos de Biomphalaria spp. (Gastropoda: Planorbidae) de dois municípios do leste da Amazônia Legal brasileira. Rev Pan-Amaz Saude 8: 51-58, 2017.

29. Santos ADM, Melo ACFL. Prevalência da esquistossomose num povoado do Município de Tutóia, Estado do Maranhão. Rev Soc Bras Med Trop 44: 97-99, 2011.

30. Scholte RG, Carvalho OS, Malone JB, Utzinger J, Vounatsou P. Spatial distribution of Biomphalaria spp., the intermediate host snails of Schistosoma mansoni, in Brazil. Geospat Health 6: S95-S101, 2012.

31. Souza CPD, Cunha RDCP, Andrade ZA. Development of Schistosoma mansoni in Biomphalaria tenagophila, Biomphalaria straminea and Biomphalaria glabrata. Rev Inst Med Trop Sao Paulo 37: 201-206, 1995.

32. Veiga-Borgeaud T, Neto RCL, Peter F, Bastos ODC. Constatações sobre a importância dos roedores silvestres (Holochilus brasiliensis nanus. Thomas, 1981) na epidemiologia da esquistossomose própria da Pré-Amazônia. Cad Pesqui 2: 86-99, 1986.

33. World Health Organization (WHO). Schistosomiasis fact sheet, 2018. Geneva, Switzerland, 2018. Available in: <https://www.who.int/news-room/fact-sheets/detail/schistosomiasis/>. Accessed in: 20/05/2020. 